\title{
Persepsi Perlindungan Hukum dan Aspek Etik terhadap Keinginan Perawat IGD Melakukan CPR pada Out-of-Hospital Cardiac Arrest (OHCA)
}

\author{
Wiwin Winarti ${ }^{1 *}$, Rosiana Rosiana ${ }^{2}$ \\ ${ }^{1}$ Keperawatan Gawat Darurat dan Bencana, Prodi Profesi Ners, Universitas Pembangunan Nasional Veteran Jakarta, \\ Jakarta, Indonesia \\ ${ }^{2}$ Mahasiswa Program Profesi Ners, Universitas Pembangunan Nasional Veteran Jakarta, Jakarta, Indonesia \\ *Email Korespondensi: wiwin.winarti@upnvj.ac.id
}

\begin{abstract}
ARTICLE INFO
HOW TO CITED:

Winarti, W \& Rosiana, R (2020). Persepsi Perlindungan Hukum dan Aspek Etik tehdapa Keinginan Perawat IGD Melakukan CPR pada Out-of-Hospital Cardiac Arrest (OHCA). Jurnal Pendidikan Keperawatan Indonesia. 6(2), p. 128-136
\end{abstract}

DOI:

10.17509/jpki.v6i2.23438

ARTICLE HISTORY:

Received

February 26, 2020

Revised

June 05, 2020

Accepted

August 11, 2020

Published

December 15, 2020

\section{ABSTRAK}

Kejadian henti jantung dapat terjadi dimana saja baik di rumah sakit maupun di luar rumah sakit atau Out-of-Hospital Cardiac Arrest (OHCA). Usaha untuk meningkatkan survival rate kejadian henti jantung adalah pemberian Cardiopulmonary resuscitation (CPR) atau resusitasi jantung paru (RJP) yang berkualitas. Faktor yang mempengaruhi seseorang untuk mau menjadi bystander CPR bukan hanya terkait pengetahuan dan teknik melakukan CPR namun juga dipengaruhi oleh faktor sosial, kerelaan melakukan, kesiapan psikologis dan faktor lainnya seperti aspek etik dan hukum. Tujuan penelitian ini untuk mengetahui pengaruh persepsi perlindungan hukum dan aspek etik terhadap keinginan perawat dalam memberikan tindakan CPR pada kejadian Out-of-Hospital Cardiac Arrest. Penelitian menggunakan desain cross-sectional dengan metode kuisioner yang dikembangkan oleh peneliti dan menggunakan total sampling yang melibatkan seluruh perawat IGD RSUD Budhi Asih sebanyak 30 orang. Analisis menggunakan uji Fisher's Exact dan Cochran-Mantel Haenszel. Hasil penelitian menunjukkan mayoritas responden $(56,7 \%)$ memiliki persepsi yang negatif terhadap perlindungan hukum terhadap bystander CPR pada OHCA. Meskipun demikian, perawat cenderung memiliki persepsi yang positif ketika menjawab pertanyaan terkait isu etik CPR pada korban anak-anak, wanita maupun lansia. Sebanyak 43,33\% (13 perawat) memiliki keinginan positif untuk melakukan CPR pada OHCA sementara $56,67 \%$ (17 perawat) lainnya memiliki keinginan negatif sebagai bystander CPR. Hasil uji Cochran-Mantel Haenszel menunjukkan persepsi terhadap perlindungan hukum mempengaruhi keinginan perawat dalam memberikan CPR pada OHCA dan akan diperbesar kemungkinan memberikan CPR apabila perawat tersebut berusia $\geq$ 30 tahun (p 0,014; OR 14,133; 95\% CI 2,081-95,947) dan memiliki masa kerja $\geq 5$ tahun (p 0,008; OR 25,667; 95\% CI 2,253-292,462). Promosi mengenai aspek legal dan etik, serta landasan hukum perlindungan terhadap bystander CPR menjadi penting untuk dapat meningkatkan keinginan perawat dan jumlah bystander CPR.

Kata Kunci: persepsi, keinginan, bystander, etik, perlindungan hukum

\section{ABSTRACT}

Cardiac arrest can occur anywhere in the hospital or outside the hospital, which is called Out-of-Hospital Cardiac Arrest (OHCA). An effort to increase the survival rate of cardiac arrest is the provision of quality Cardiopulmonary resuscitation (CPR). Factors that influence a person's willingness to become a bystander CPR are not only related to the knowledge and techniques of conducting CPR but are 
Winarti, W \& Rosiana, R.| Persepsi Perlindungan Hukum dan Aspek Etik terhadap Keinginan Perawat IGD Melakukan ...

also influenced by social factors, willingness, psychological readiness, and other factors such as ethical and legal aspects. The purpose of this study is to determine the effect of perceptions of legal protection and ethical issues on the nurses' willingness to provide CPR in the OHCA incident. This study used a cross-sectional design using a questionnaire developed by researchers, conducted at Emergency Department Budhi Asih Regional Hospital in East Jakarta, and used a total sampling method involving 30 ED nurses. Fisher's Exact and Cochran-Mantel Haenszel tests were used to analyze the data. The study findings show that the majority of respondents (56.7\%) have a negative perception of the legal protection of bystander CPR in OHCA. However, nurses have a positive perception when answering questions related to the ethical issue of CPR in victims of children, women, and the elderly. $43.33 \%$ (13 nurses) have a positive willingness to perform CPR on OHCA, while $56.67 \%$ (17 nurses) have a negative willingness as a bystander CPR. The results of the Cochran-Mantel Haenszel test show that perceptions of legal protection may influence nurses' willingness to provide CPPR to OHCA patient, and it will increase the likelihood of giving CPR if the nurse age is $\geq 30$ years old ( $p$ 0.014; OR 14,133; 95\% CI 2,081-95,947) and has been working for $\geq 5$ years ( $p$ 0.008; OR 25,667; 95\% CI 2,253-292,462). Promotion of the legal aspects, ethical issues, and protection to bystander CPR is essential to increase the willingness of nurses and the number of bystander CPR.

Keyword: perception, willingness, bystander, ethical, legal protection

\section{PENDAHULUAN}

Kejadian henti jantung dapat terjadi dimana saja baik di rumah sakit maupun di luar rumah sakit atau Out-of-Hospital Cardiac Arrest (OHCA) (Kronick dkk., 2015). Prevalensi terjadinya OHCA tercatat tinggi di berbagai negara. Sebuah penelitian yang dilakukan di negara Eropa menemukan 34\% dari 514 kejadian henti jantung merupakan OHCA (Gräsner dkk., 2016). Penelitian lain di Amerika menyebutkan 326.000 kasus henti jantung terjadi setiap tahunnya dimana kasus OHCA tercatat sebanyak 132 kasus per 100.000 populasi (Kronick dkk., 2015). Gambaran tingginya angka kejadian henti jantung juga ditemukan di Indonesia dimana henti jantung tercatat mencapai $300.000-350.000$ setiap tahunnya yang mencakup kejadian di dalam maupun diluar rumah sakit (PERKI, 2015).

Usaha untuk meningkatkan survival rate kejadian henti jantung adalah pemberian Cardiopulmonary resuscitation (CPR) atau resusitasi jantung paru (RJP) yang berkualitas. Pemberian CPR yang berkualitas dapat dilakukan oleh siapa saja, namun pemberian CPR lebih baik dilakukan oleh tenaga medis (AHA, 2015). Perawat yang merupakan bagian dari tenaga medis dapat memberikan CPR yang berkualitas karena dilengkapi dengan kemampuan Basic Life Support (BLS), Intermediate Life Support (ILS), ataupun
Advanced Life Support (ALS) (Alenyo, Smith, McCaul, \& Van Hoving, 2018). Namun pada kenyataanya jumlah bystander CPR OHCA yang merupakan tenaga medis ditemukan lebih sedikit dibandingkan bystander yang bukan tenaga medis. Sebuah penelitian di Malaysia menemukan dari 389 kejadian OHCA, bystander CPR yang merupakan tenaga medis hanya sebesar 2,6\% sedangkan 22,6\% ditolong oleh bystander yang bukan tenaga medis (Ong dkk., 2016).

Faktor yang mempengaruhi seseorang untuk mau menjadi bystander CPR bukan hanya terkait pengetahuan dan teknik melakukan CPR namun juga dipengaruhi oleh faktor sosial, kerelaan melakukan, kesiapan psikologis dan faktor lainnya (Lu dkk., 2016). Memberikan CPR pada kelompok rentan seperti anak-anak dan lansia juga dapat menimbulkan stress pada penolong karena masalah aspek legal dan etik. Mendapatkan kasus CPR pada anak - anak dan pemberian dosis obat merupakan hal yang sulit dilakukan karena fisiologis anak berbeda dengan dewasa (Bohström dkk., 2017). Sama halnya dengan CPR pada anak, kerentanan fisik lansia juga menjadikan pertimbangan bystander dimana sebuah penelitian menemukan $63,1 \%$ responden menyatakan bahwa kekhawatiran akan menyebabkan injuri pada lansia mengurangi keinginan mereka untuk memberikan CPR pada lansia (Becker dkk., 2018). 
Kekhawatiran ini dapat berdampak pada survival rate OHCA lansia dimana penelitian terdahulu menemukan bahwa lansia memiliki survival rate CPR yang rendah dibandingkan dengan kelompok yang lebih muda ( $4,8 \%$ berbanding $10,7 \%$ ) (Wiel dkk., 2017).

Bystander juga memiliki kekhawatiran ketika memberikan CPR pada wanita terkait aspek perlindungan hukum. Sebuah penelitian di Amerika menemukan bahwa 33,8\% responden pria yang merupakan penduduk Amerika takut akan stigma sosial dan tuntutan pelecehan berkaitan dengan tubuh wanita. Responden khawatir bahwa dirinya akan mendapatkan tuntutan pelecehan seksual atau pemerkosaan jika melakukan CPR pada wanita (Perman dkk., 2019). Keyakinan akan perlindungan hukum dan persepsi yang baik mengenai aspek etik dan legal CPR terutama pada anak, wanita dan lansia menjadi aspek penting dalam keinginan individu dalam memberikan CPR pada kejadian OHCA. Sebuah penelitian di China bahkan menemukan bahwa mahasiswa jurusan medis $(38,7 \%)$ dan keperawatan $(39,6 \%)$ adalah kelompok yang paling banyak menyatakan kekhawatiran mengenai aspek legal dalam pemberian CPR terutama pada kelompok rentan seperti anak dan lansia (Lu dkk., 2015). Indonesia sendiri memiliki landasan mengenai pertolongan korban gawat darurat salah satunya yaitu pada KUHP (Kitab Undang - Undang Hukum Pidana) pasal 531, Undang - undang (UU) No. 36 Tahun 2009 Tentang Kesehatan, dan UU No. 38 Tentang Keperawatan. Namun, belum diketahui sejauh mana pemahaman dan persepsi tenaga kesehatan terutama perawat mengenai dasar hukum yang dapat melindungi tindakan pertolongan pada kondisi gawat darurat seperti CPR maupun apakah pengetahuan dan persepsi mengenai legal etik dalam CPR mempengaruhi keinginan perawat dalam memberikan CPR ditempat umum. Untuk itu, penelitian ini bertujuan untuk mengetahui pengaruh persepsi perlindungan hukum dan aspek etik terhadap keinginan perawat IGD RSUD Budhi Asih dalam memberikan tindakan CPR pada kejadian OHCA.

\section{METODE}

Penelitian menggunakan desain crosssectional yang dilakukan di IGD RSUD Budhi Asih Jakarta Timur dalam kurun waktu Maret hingga Mei 2019. Penelitian menggunakan total sampling yang melibatkan seluruh perawat IGD RSUD Budhi Asih sebanyak 30 orang. Kriteria inklusi yang digunakan meliputi perawat IGD, telah berdinas di IGD minimal 1 tahun sebelum penelitian dilakukan untuk mengidentifikasi pengalaman bekerja perawat terkait pengaruhnya terhadap variabel independen dan dependen yang diteliti, serta memiliki sertifikat pelatihan BTCLS yang masih berlaku sebagai provider CPR. Kriteria eksklusi yang digunakan adalah perawat yang diperbantukan dari ruangan lain ke IGD. Data penelitian diambil menggunakan metode kuisioner yang dikembangkan oleh peneliti, yang terbagi menjadi 3 bagian. Bagian pertama berisi data demografi perawat yang memiliki potensi mempengaruhi variable utama. Bagian kedua berisikan pertanyaan mengenai persepsi responden mengenai perlindungan hukum dan bagian terakhir berisi pertanyaan terkait aspek etik mengenai CPR. Pilihan jawaban pertanyaan terkait persepsi terhadap perlindungan hukum dan etik serta keinginan perawat menjadi bystander CPR OHCA disajikan dalam skala likert. Kuisioner telah diujikan validitas dan realibilitasnya dengan nilai alfa chronbach untuk pertanyaan perlindungan hukum sebesar 0,808 , nilai untuk pertanyaan aspek etik adalah 0,906 dan nilai untuk pertanyaan keinginan untuk memberikan CPR pada OHCA sebesar 0,850 . Data kemudian dianalisa dalam bentuk dikotomi dengan memakai nilai mean sebagai cut of point pada variable persepsi perlindungan hukum, aspek etik dan keinginan untuk melakukan CPR pada OHCA. Analisis menggunakan uji Fisher's Exact dan selanjutnya Cochran-Mantel Haenszel digunakan untuk mengontrol variable karakteristik responden yang signifikan mempengaruhi hubungan variable utama. Penelitian telah memperoleh ijin dari komite etik penelitian Universitas Pembangunan Nasional Veteran Jakarta dengan nomor surat B/2017/VI/2019/KEPK. 
Winarti, W \& Rosiana, R.| Persepsi Perlindungan Hukum dan Aspek Etik terhadap Keinginan Perawat IGD Melakukan ...

HASIL

Penelitian menemukan bahwa mayoritas responden memiliki persepsi yang negatif $(56,7 \%)$ terhadap perlindungan hukum terhadap bystander CPR pada korban henti jantung di publik. Meskipun demikian, perawat cenderung memiliki persepsi yang positif ketika menjawab pertanyaan terkait isu etik CPR pada korban anak-anak, wanita maupun lansia. Penelitian juga menemukan bahwa persepsi positif perawat cenderung lebih baik ketika dihadapkan pada korban CPR lansia dan wanita dewasa dibandingkan dengan anak-anak (tabel 1).

Tabel 1. Distribusi Persepsi Perawat Terhadap Perlindungan Hukum dan Isu Etik Bystander CPR pada OHCA

\begin{tabular}{|c|c|c|c|c|c|c|}
\hline \multirow{3}{*}{ Variabel } & \multicolumn{6}{|c|}{ Persepsi Perawat } \\
\hline & \multicolumn{2}{|c|}{ Positif } & \multicolumn{2}{|c|}{ Negatif } & \multicolumn{2}{|c|}{ Total } \\
\hline & $\mathbf{n}$ & $\%$ & $\mathbf{n}$ & $\%$ & $\mathbf{n}$ & $\%$ \\
\hline Perlindungan Hukum Bystander CPR OHCA & 13 & 43,3 & 17 & 56,7 & 30 & 100 \\
\hline Isu Etik CPR OHCA pada Anak & 18 & 60,0 & 12 & 40,0 & 30 & 100 \\
\hline Isu Etik CPR OHCA pada Wanita & 20 & 66,7 & 10 & 33,3 & 30 & 100 \\
\hline Isu Etik CPR OHCA pada Lansia & 22 & 73,3 & 8 & 26,7 & 30 & 100 \\
\hline
\end{tabular}

Tabel 2. Distribusi Keinginan Melakukan CPR pada OHCA Berdasarkan Usia, Jenis Kelamin dan Lama Kerja

\begin{tabular}{|c|c|c|c|c|c|c|c|c|}
\hline \multirow{3}{*}{ Variabel } & \multicolumn{6}{|c|}{ Keinginan Melakukan CPR pada OHCA } & \multirow{3}{*}{ P-Value } & \multirow{3}{*}{ OR $(95 \%$ CI $)$} \\
\hline & \multicolumn{2}{|c|}{ Positif } & \multicolumn{2}{|c|}{ Negatif } & \multicolumn{2}{|c|}{ Total } & & \\
\hline & $\mathbf{n}$ & $\%$ & $\mathbf{n}$ & $\%$ & $\mathbf{n}$ & $\%$ & & \\
\hline \multicolumn{9}{|l|}{ Usia } \\
\hline$<30$ tahun & 3 & 23,1 & 11 & 64,7 & 14 & 46,7 & $0,033^{*}$ & 0,164 \\
\hline$\geq 30$ tahun & 10 & 76,9 & 6 & 35,3 & 16 & 53,3 & & $(0,032-0,834)$ \\
\hline Total & 13 & 100 & 17 & 100 & 30 & 100 & & \\
\hline \multicolumn{9}{|l|}{ Jenis Kelamin } \\
\hline Laki-Laki & 4 & 30,8 & 9 & 52,9 & 13 & 43,3 & 0,283 & 0,395 \\
\hline Perempuan & 9 & 69,2 & 8 & 47,1 & 17 & 56,7 & & $(0,087-1,797)$ \\
\hline Total & 13 & 100 & 17 & 100 & 30 & 100 & & \\
\hline \multicolumn{9}{|l|}{ Lama Kerja } \\
\hline$<5$ tahun & 1 & 7,7 & 9 & 52,9 & 10 & 33,3 & $0,017 *$ & 0,074 \\
\hline$\geq 5$ tahun & 12 & 92,3 & 8 & 47,1 & 20 & 66,7 & & $(0,008-0,704)$ \\
\hline Total & 13 & 100 & 17 & 100 & 30 & 100 & & \\
\hline
\end{tabular}

Tabel 3. Distribusi Keinginan Melakukan CPR pada OHCA Berdasarkan Persepsi Perlindungan Hukum dan Aspek Etik

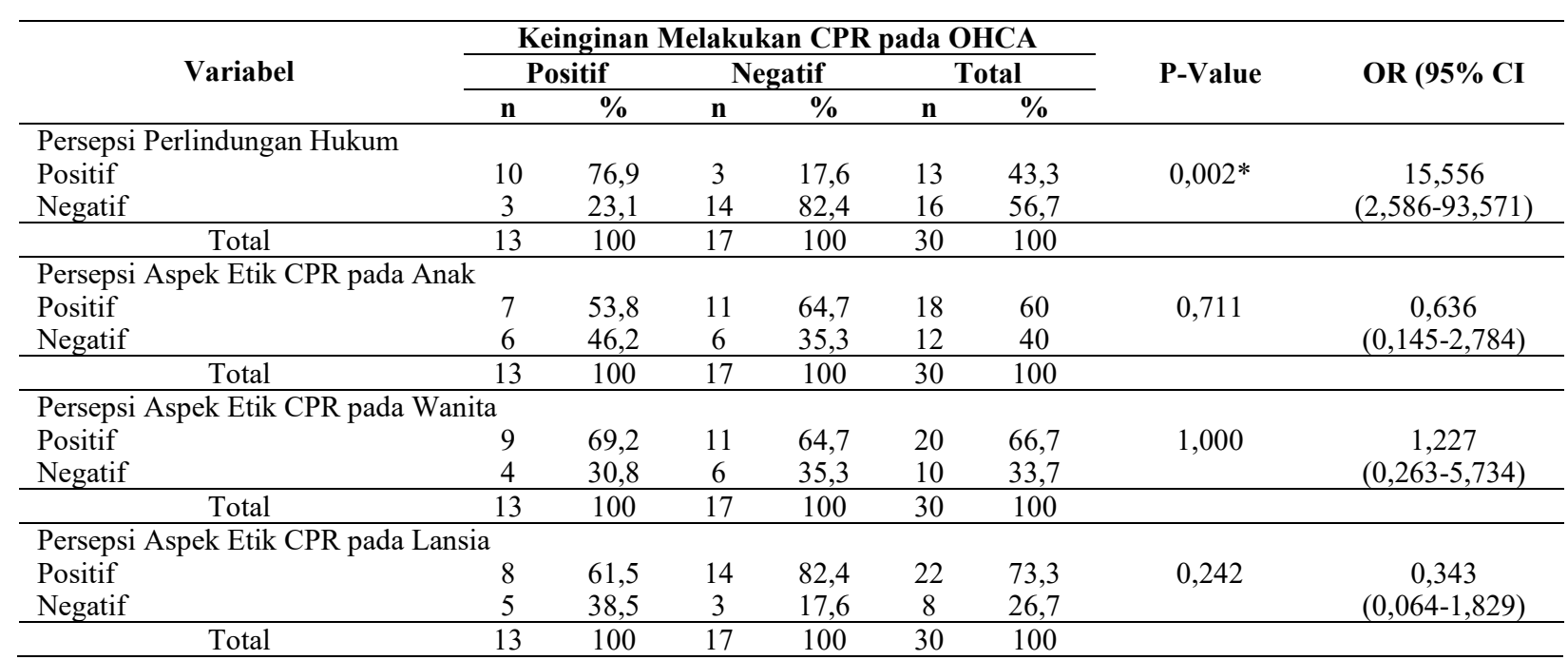

Uji Fisher's Exact 
Berdasarkan karakteristik responden (tabel 2), faktor yang ditemukan mempengaruhi keinginan perawat IGD untuk melakukan CPR pada OHCA adalah usia dan lama kerja perawat ditugaskan di IGD. Kelompok perawat yang memiliki keinginan positif untuk melakukan CPR pada OHCA mayoritas berada pada kelompok berusia lebih dari sama dengan 30 tahun dan memiliki lama kerja lebih dari sama dengan lima tahun. Sementara itu, jenis kelamin tidak memiliki pengaruh terhadap keinginan perawat dalam melakukan CPR pada OHCA $(p=0,283)$. Namun demikian, dapat terlihat bahwa perawat perempuan lebih banyak yang memiliki keinginan yang positif $(69,2 \%)$ dibandingkan perawat laki-laki.

Hasil penelitian menemukan bahwa variable utama persepsi terhadap perlindungan hukum mempengaruhi keinginan perawat untuk melakukan CPR pada OCHA (tabel 3). Perawat yang memiliki persepsi perlindungan hukum positif, mayoritas memiliki keinginan positif untuk memberikan CPR pada OCHA. Sebaliknya, perawat yang memiliki persepsi negatif terhadap perlindungan hukum, mayoritas juga memiliki keinginan negatif untuk memberikan CPR. Nilai OR $(15,556)$ menunjukkan bahwa perawat yang memiliki persepsi perlindungan hukum yang positif akan memiliki keinginan positif 15,556 kali lebih besar untuk memberikan CPR pada OHCA dibandingkan mereka yang memiliki persepsi perlindungan hukum yang negatif (tabel 3).

Persepsi mengenai aspek etik pemberian CPR pada anak, wanita maupun lansia ditemukan tidak memiliki pengaruh pada keinginan responden dalam memberikan CPR pada OHCA. Penelitian menemukan bahwa meskipun mayoritas perawat memiliki persepsi yang positif terhadap isu etik pemberian CPR pada OHCA anak, wanita dewasa dan lansia, hanya sebagian dari perawat tersebut yang memiliki keinginan positif untuk memberikan CPR pada korban OHCA anak, wanita dewasa dan lansia (tabel 3). Penelitian juga menemukan bahwa perawat lebih memiliki keinginan positif untuk memberikan CPR pada korban wanita dewasa $(69,2 \%)$ dibandingkan dengan koban lansia $(61,5 \%)$ dan anak $(58,3 \%)$.

Tabel 4. Hasil Uji Stratifikasi Cochran-Mantel Haenszel Persepsi Perlindungan Hukum dengan Usia dan Lama Kerja

\begin{tabular}{|c|c|c|c|c|c|c|c|c|c|}
\hline \multirow{3}{*}{\multicolumn{2}{|c|}{ Variabel }} & \multicolumn{6}{|c|}{ Keinginan Melakukan CPR pada OHCA } & \multirow{3}{*}{ P-Value } & \multirow{3}{*}{ OR $(95 \%$ CI } \\
\hline & & \multicolumn{2}{|c|}{ Positif } & \multicolumn{2}{|c|}{ Negatif } & \multicolumn{2}{|c|}{ Total } & & \\
\hline & & $\mathbf{n}$ & $\%$ & $\mathbf{n}$ & $\%$ & $\mathbf{n}$ & $\%$ & & \\
\hline \multicolumn{10}{|c|}{ Usia dan Persepsi Hukum } \\
\hline$<30$ tahun & Positif & 2 & 66,7 & 2 & 18,2 & 4 & 28,6 & \multirow{4}{*}{0,014} & \multirow{4}{*}{$\begin{array}{c}14,133 \\
(2,081-95,974)\end{array}$} \\
\hline & Negatif & 1 & 33,3 & 9 & 81,8 & 10 & 71,4 & & \\
\hline \multirow[t]{2}{*}{$\geq 30$ tahun } & Positif & 8 & 80 & 1 & 16,7 & 9 & 56,3 & & \\
\hline & Negatif & 2 & 20 & 5 & 83,3 & 7 & 43,8 & & \\
\hline \multicolumn{10}{|c|}{ Lama Kerja dan Persepsi Hukum dan Lama Kerja } \\
\hline$<5$ tahun & Positif & 1 & 100 & 2 & 22,2 & 3 & 30 & \multirow{4}{*}{0,008} & \\
\hline & Negatif & 0 & 0 & 7 & 77,8 & 7 & 70 & & 25,667 \\
\hline \multirow[t]{2}{*}{$\geq 5$ tahun } & Positif & 9 & 80 & 1 & 16,7 & 10 & 50 & & $(2,253-292,462)$ \\
\hline & Negatif & 3 & 20 & 7 & 83,3 & 10 & 50 & & \\
\hline
\end{tabular}

Uji Cochran-Mantel Haenszel

Tabel 4 menunjukkan hasil uji stratifikasi terhadap pengaruh persepsi perlindungan hukum terhadap keinginan melakukan CPR pada OHCA dengan mengontrol variable usia dan lama kerja yang ditemukan memiliki pengaruh signifikan terhadap keinginan melakukan CPR pada OHCA $(p<0,05)$. Penelitian menemukan bahwa keinginan positif melakukan CPR pada OHCA lebih tinggi pada perawat yang memiliki persepsi hukum positif dan akan diperbesar kemungkinan memberikan CPR apabila perawat tersebut berusia 30 tahun atau lebih (OR 14,133; 95\% CI 2,08195,974). Tabel 4 juga menunjukkan bahwa pengalaman kerja 5 tahun atau lebih juga 
memperbesar probabilitas perawat yang memiliki persepsi hukum positif untuk melakukan CPR pada OHCA (OR 25,667; 95\% CI 2,253292,462).

\section{PEMBAHASAN}

\section{Perlindugan Hukum Bystander CPR OHCA}

Hasil penelitian menunjukkan bahwa persepsi terhadap perlindungan hukum signifikan mempengaruhi keinginan bystander CPR, dimana persepsi yang baik terhadap perlindungan hukum akan menyebabkan orang memiliki keinginan untuk melakukan CPR pada OHCA $(\mathrm{p}=0,002)$ (tabel 3). Bystander memerlukan keyakinan akan perlindungan hukum terhadap tindakan penyelamatan yang dilakukannya agar terhindar dari masalah hukum dan stigma sosial. Penelitian di China menemukan bahwa kekhawatiran yang paling besar ketika memberikan CPR pada orang yang tidak dikenal adalah masalah hukum atau aspek legal (53,2\%) (Meng dkk., 2017). Minimnya kebijakan terkait resusitasi menjadi tantangan dalam praktik pemberian CPR dan harus menjadi agenda penting dalam pembahasan di tingkat nasional (Haidar, 2016). Negara-negara seperti Amerika, Kanada, dan banyak negara Eropa memiliki hukum "Good Samaritan Law" (GSL) yang melindungi bystander dalam memberikan pertolongan pada korban, mendorong orang untuk membantu korban yang membutuhkan pertolongan, dan menurunkan rasa ragu dan takut bystander terhadap tuntutan akibat cedera atau kematian yang diakibatkan karena tindakan pertolongan yang diberikan. Hukum ini menyebabkan jumlah bystander di negara-negara tersebut diatas lebih banyak dibandingkan negara yang tidak menerapkan "Good Samaritan Law" (Meng dkk., 2017). Meng dan kolega dalam penelitiannya yang melibatkan 2094 responden yang $12,1 \%$ diantaranya adalah petugas kesehatan menyatakan bahwa di China alasan utama yang mencegah orang melakukan CPR pada OHCA adalah masalah perlindungan hukum disamping kurangnya pengetahuan dan skill CPR (Meng dkk., 2017). Penelitiaan lain juga menyatakan bahwa kurangnya perlindungan Hukum (GSL) menjadi salah satu faktor rendahnya survival rate pada OHCA (Hung, Leung, Siu, \& Graham, 2019).

\section{Perlindungan Hukum, Isu Etik, dan Keinginan Menjadi Bystander CPR OHCA}

Penelitian di Amerika yang melibatkan 542 responden menemukan bahwa perlindungan hukum sangat penting karena dapat mengurangi kekhawatiran untuk mendapatkan tuntutan terutama pada pemberian CPR pada wanita (Perman dkk., 2019). Meskipun dalam penelitian ini belum dapat membuktikan secara statistik pengaruh aspek etik CPR pada wanita, anak-anak maupun lansia terhadap keinginan menjadi bystander CPR ( $p>0,05)$, hasil menunjukkan mayoritas responden memiliki keinginan negatif untuk memberikan CPR pada kelompok wanita, anak-anak, maupun lansia (tabel 3). Penelitian terdahulu memberikan gambaran yang serupa. Penelitian Perman dan kolega menemukan bahwa $33,8 \%$ dari responden pria takut akan stigma sosial dan tuntutan pelecehan berkaitan dengan tubuh wanita. Ketakutan tersebut diantaranya adalah tuduhan menyentuh area dada wanita dan mencium wanita saat pemberian bantuan napas buatan (Perman dkk, 2019). Penelitian lain juga menemukan hal yang sama dimana kekhawatiran karena harus mengekspos dada pasien dikemukakan oleh $14,1 \%$ responden dan $6 \%$ lainnya takut dituduh melecehkan korban sehingga mempengaruhi keinginan memberikan CPR pada wanita (Becker dkk., 2018).

Selain aspek pemberian CPR pada wanita, bystander juga memiliki kekhawatiran jika harus menjadi bystander CPR lansia dan anak-anak. Penelitian ini menemukan bahwa jumlah responden yang memiliki keinginan positif untuk memberikan CPR pada lansia dan anak lebih sedikit dibandingkan bystander CPR pada wanita (tabel 3). Terlebih lagi, 14 dari 22 responden yang memiliki persepsi positif tentang aspek etik CPR terhadap lansia memilki keinginan negatif menjadi bystander CPR pada lansia (tabel 3). Penelitian terdahulu yang dilakukan di Hongkong terhadap 1223 peserta pelatihan resusitasi dari Hongkong St. 
John Ambulance dan Hongkong Red Cross menemukan hal serupa. Dari 85\% responden yang setuju bahwa bystander memiliki kewajiban moral untuk memberikan CPR pada korban, hanya 55\% diantaranya yang menjawab setuju mau memberikan CPR pada OHCA lansia (Hung dkk, 2019). Dua penelitian lain yang dilakukan di Amerika dan China juga menggambarkan hal serupa dimana keinginan mejadi bystander CPR pada lansia dan anak-anak lebih sedikit dibandingkan kelompok usia lainnya (Becker dkk., 2018; Bs dkk., 2015). Alasan yang ditemukan dalam penelitian terdahulu terkait keengganan memberikan CPR pada lansia dan anak-anak berkaitan dengan fisik korban dan kekhawatiran masalah hukum setelahnya. Pada penelitiannya, Becker dan kawan-kawan menemukan 63\% responden menyatakan alasan kekhawatiran dalam memberikan CPR pada lansia adalah takut menyebabkan injuri dan 2\% responden lainnya menyatakan takut disalahkan oleh orang lain. Alasan yang sama juga tampak pada pernyataan CPR pada anak dimana mayoritas responden takut menyebabkan injuri pada anak $(50,9 \%)$ dan takut disalahkan oleh orang tua korban $(5,2 \%)$ (Becker dkk., 2018).

Pentingnya promosi mengenai aspek legal dan landasan hukum perlindungan kepada bystander CPR tampaknya menjadi penting untuk dapat meningkatkan jumlah bystander CPR. Meskipun Indonesia memiliki landasan hukum yang terdiri dari KUHP (Kitab Undang - Undang Hukum Pidana) pasal 531, Undang - undang (UU) No. 36 Tahun 2009 Tentang Kesehatan, dan UU No. 38 Tentang Keperawatan, namun jumlah perawat dalam penelitian ini yang memiliki persepsi positif terhadap perlindungan hukum hanya 43,3\% (tabel 3). Meskipun demikian, dari penelitian ditemukan bahwa responden yang memiliki persepsi positif terhadap perlindungan hukum memiliki OR 15,556 (95\% CI 2,58693,571) untuk memiliki keinginan yang positif menjadi Bystander CPR (tabel 3). Temuan ini didukung oleh penelitian sebelumnya dimana ketika responden diyakinkan jika ada perlindungan hukum untuk mencegah bystander terkena masalah hukum, keinginan memberikan CPR pada OHCA mencapai 88,5\% (Chen dkk., 2017). Penelitian lain di China juga menemukan bahwa responden yang memiliki pemahaman tentang hukum cenderung memiliki keinginan yang tinggi untuk menjadi bystander CPR. Lu dan kolega menemukan $70 \%$ mahasiswa jurusan hukum menyatakan akan memberikan CPR jika bertemu korban yang memerlukan. Tingginya keinginan menjadi bystander CPR pada kelompok ini dikarenakan mereka memahami aspek hukum yang dapat melindungi mereka dari konsekuensi hukum jika menjadi bystander CPR (Bs dkk., 2015).

\section{Usia, Lama Kerja Dan Keinginan Perawat Menjadi Bystander OHCA}

Analisis stratifikasi yang dilakukan terhadap pengaruh persepsi terhadap keinginan melakukan CPR menemukan bahwa usia $(\mathrm{p}=0,014)$ dan lama kerja $(p=0,008)$ mempengaruhi persepsi perawat terhadap perlindungan hukum dalam CPR yang selanjutnya mempengaruhi keinginan mereka dalam memberikan CPR pada OHCA (tabel 4). Perawat yang berusia lebih dari 30 tahun memiliki keinginan yang lebih besar untuk memberikan CPR jika dihadapkan pada pasien OHCA (OR= $14,133 ; \mathrm{p}=0,014)$. Usia tampak mempengaruhi keinginan perawat dalam meberikan CPR. Dua penelitian sebelumnya juga menemukan bahwa usia bystander yang paling banyak memiliki keinginan positif memberikan CPR berada pada rentang 30-54 tahun (Dobbie, MacKintosh, Clegg, Stirzaker, \& Bauld, 2018; Zhou dkk., 2019). Selain itu, lama kerja juga memberikan pengaruh terhadap keinginan dalam memberikan CPR pada OHCA dimana semakin lama bekerja di unit gawat darurat semakin positif keinginan dalam meberikan CPR pada OHCA $(\mathrm{OR}=25,667$; $\mathrm{p}=0,008$ ) (tabel 4). Temuan ini sejalan dengan penelitian Kozamani dan kolega tentang perilaku perawat dalam memberikan pertolongan pada pasien OHCA. Dalam penelitiannya ditemukan bahwa lama bekerja mempengaruhi perilaku perawat dalam memberikan CPR $(\mathrm{p}=0,002)$ dimana perawat yang bekerja lebih dari 10 tahun memiliki kepercayaan diri yang lebih baik dalam 
memberikan CPR pada OHCA (Kozamani, Kapadochos, \& Kadda, 2012). Dalam penelitiannya disimpulkan bahwa semakin lama pengalaman perawat akan sejalan dengan banyaknya pelatihan dan pengalaman perawat dalam memberikan CPR sehingga berdampak pada kepercayaan diri dalam memberikan CPR pada OHCA (Kozamani dkk., 2012).

Kelemahan dari penelitian ini adalah jumlah responden yang sedikit dan terbatas pada perawat IGD yang menjadikan hasil penelitian kurang dapat digeneralisasikan pada kelompok yang lebih luas. Penelitian ini juga tidak menanyakan alasan spesifik dalam bentuk open ended question untuk dapat menganalisis lebih dalam alasan yang mendukung maupun mencegah keinginan menjadi bystander CPR. Penelitian ini telah menggunakan analisis stratifikasi yang dapat mengontrol variabel pengganggu yang dapat mempengaruhi hasil penelitian.

\section{SIMPULAN}

Penelitian membuktikan bahwa persepsi positif terhadap perlindungan hukum merupakan hal yang berpengaruh kepada keinginan perawat

\section{DAFTAR PUSTAKA}

Alenyo, A. N., Smith, W. P., McCaul, M., \& Van Hoving, D. J. (2018). A Comparison between Differently Skilled Prehospital Emergency Care Provider $\mathrm{s}$ in MajorIncident Triage in South Africa. Prehospital and Disaster Medicine, 1-6. https://doi.org/ 10.1017/ S1049023X18000699

American Heart Association. (2015). Guidelines $2015 C P R$ and ECC. 34. https://doi.org/ 10.1016/j.neulet.2006.10.016

Becker, T. K., Gul, S. S., Cohen, S. A., Maciel, C. B., Baron-lee, J., Murphy, T. W., ... Shelton, S. K. (2018). Resuscitation of out-ofhospital cardiac arrest victims in Lebanon: The experience and views of prehospital providers. Journal of Emergencies, Trauma and Shock, 11(3), 183-188. https://doi.org/ http://dx.doi.org/10.4103/JETS.JETS_101_17 memberikan bantuan CPR pada OHCA. Persepsi yang positif akan memperbesar peluang perawat untuk menjadi bystander CPR pada OHCA. Penelitian ini menunjukkan bahwa promosi mengenai aspek legal dan etik terutama landasan hukum di Indonesia yang melindungi bystander CPR penting untuk dilakukan. Promosi terutama dapat diberikan dalam pelatihan-pelatihan CPR dan dalam kurikulum pendidikan keperawatan sehingga akan lebih banyak perawat yang memiliki persepsi yang positif terhadap perlindungan hukum untuk bystander CPR. Penelitian selanjutnya yang membahas pemahaman perawat mengenai aspek perlindungan hukum bystander CPR dan pengaruhnya terhadap perilaku sebagai bystander CPR perlu dilakukan dengan menggunakan desain penelitian yang lebih baik dan jumlah sampel yang lebih banyak.

\section{UCAPAN TERIMA KASIH}

Terima kasih kami ucapkan kepada pihak UPN Veteran Jakarta, RSUD Budhi Asih dan semua responden yang telah berpartisipasi dalam penelitian ini.

Bohström, D., Carlström, E., \& Sjöström, N. (2017). Managing stress in prehospital care: Strategies used by ambulance nurses. International Emergency Nursing, 32, 2833. https://doi.org/10.1016/j.ienj.2016.08.004

Bs, C. L., Jin, Y., Lecturer, R. N., Ms, F. M., Bs, Y. W., Bs, X. S., ... Bs, Q. X. (2015). An exploration of attitudes toward bystander cardiopulmonary resuscitation in university students in Tianjin, China: A survey. International Emergency Nursing. https:// doi.org/10.1016/j.ienj.2015.05.006

Chen, M., Wang, Y., Li, X., Hou, L., Wang, Y., Liu, J., \& Han, F. (2017). Public knowledge and attitudes towards bystander cardiopulmonary resuscitation in China. BioMed research international, 2017.

Dobbie, F., MacKintosh, A. M., Clegg, G., Stirzaker, R., \& Bauld, L. (2018). Attitudes 
towards bystander cardiopulmonary resuscitation: Results from a cross-sectional general population survey. PLOS ONE, 13(3), 1-8. https://doi.org/10.1371/journal. pone. 0193391

Gräsner, J. T., Lefering, R., Koster, R. W., Masterson, S., Böttiger, B. W., Herlitz, J., ... Bossaert, L. L. (2016). EuReCa ONE-27 Nations, ONE Europe, ONE Registry: A prospective one month analysis of out-ofhospital cardiac arrest outcomes in 27 countries in Europe. Resuscitation, 105, 188195. https://doi.org/10.1016/j.resuscitation. 2016.06.004

Haidar, M. H. (2016). Survey of paramedic personnel on attitudes and practices related to resuscitation of out of hospital cardiac arrest victims in Lebanon. Theses, Dissertations, and Projects.

Hung, K. K. C., Leung, C. Y., Siu, A., \& Graham, C. A. (2019). Good Samaritan Law and bystander cardiopulmonary resuscitation: Cross-sectional study of 1223 first -aid learners in Hong Kong. Hong Kong Journal of Emergency Medicine https://doi.org/ 10.1177/1024907919870928

Kozamani, A., Kapadochos, T., \& Kadda, O. (2012). Factors that influence nursing staff attitudes towards initiating CPR and in using an automatic external defibrillator when outside of a hospital. Health Science Journal, 6(1), 88-101.

Kronick, S. L., Kurz, M. C., Lin, S., Edelson, D. P., Berg, R. A., Billi, J. E., ... Welsford, M. (2015). Part 4: Systems of care and continuous quality improvement: 2015 American Heart Association guidelines update for cardiopulmonary resuscitation and emergency cardiovascular care. Circulation, 132(18), S397-S413. https://doi.org/10. 1161/CIR.0000000000000258

Lu, C., Jin, Y. hui, Shi, X. tong, Ma, W. jing, Wang, Y. yun, Wang, W., \& Zhang, Y. (2016). Factors influencing Chinese university students' willingness to performing bystander cardiopulmonary resuscitation. International Emergency Nursing, 32, 3-8. https://doi.org/10.1016/ j.ienj.2016.04.001
Lu, C., Jin, Y., Meng, F., Wang, Y., Shi, X., Ma, W., ... Xing, Q. (2015). An exploration of attitudes toward bystander cardiopulmonary resuscitation in university students in Tianjin, China: A survey. International Emergency Nursing. https://doi.org/10.1016/j.ienj.2015. 05.006

Meng, C., Yue, W., Fei, H., Lina, H., Xuan, L., Yufeng, W., \& Jie, L. (2017). Public Knowledge and Attitudes towards Bystander Cardiopulmonary Resuscitation in China. BioMed Research International, 2017, 1-7. https://doi.org/10.1155/2017/3250485

Ong, M. E. H., Shin, S. Do, De Souza, N. N. A., Tanaka, H., Nishiuchi, T., Song, K. J., ... Ma, M. H. M. (2016). Corrigendum to "Outcomes for out-of-hospital cardiac arrests across 7 countries in Asia: The Pan Asian Resuscitation Outcomes Study (PAROS)" [Resuscitation 96 (2015) 100-108] DOI: 10.1016/j.resuscitation.2015.07.026.

Resuscitation, 98, 125-126. https://doi.org/ 10.1016/j.resuscitation.2015.11.002

PERKI. (2015). Henti jantung. Heart.Org, 2.

Perman, S. M., Shelton, S. K., Knoepke, C., Rappaport, K., Matlock, D. D., Adelgais, K., ... Daugherty, S. L. (2019). Public Perceptions on Why Women Receive Less Bystander Cardiopulmonary Resuscitation Than Men in Out-of-Hospital Cardiac Arrest. Circulation, 139(8), 1060-1068. https:// doi.org/10.1161/CIRCULATIONAHA.118. 037692

Wiel, E., Di Pompéo, C., Segal, N., Luc, G., Marc, J.-B., Vanderstraeten, C., ... Hubert, H. (2017). Age discrimination in out-of-hospital cardiac arrest care: a case-control study. European Journal of Cardiovascular Nursing, 17(6), 505-512. https://doi.org/ $10.1177 / 1474515117746329$

Zhou, G., Lu, G., Shi, O., Li, X., Wang, Z., Wang, Y., \& Luo, Q. (2019). Willingness and obstacles of healthcare professionals to perform bystander cardiopulmonary resuscitation in China. International Emergency Nursing, 47(July), 100788. https://doi.org/10.1016/j.ienj.2019.100788 
Winarti, W \& Rosiana, R. | Persepsi Perlindungan Hukum dan Aspek Etik terhadap Keinginan Perawat IGD Melakukan ... 